\title{
$\angle S$ Research Soure \\ Relationship of dietary energy and protein during peripartum and lactation in Pelibuey ewes infected with gastrointestinal nematodes
}

\section{Yoel López-Leyva}

Universidad de Matanzas Camilo Cienfuegos

Roberto González Garduño ( $\square$ robgardu@hotmail.com )

Universidad Autónoma Chapingo: Universidad Autonoma Chapingo https://orcid.org/0000-0003-0333-

7787

\section{Javier Arece-García}

Universidad de Matanzas Camilo Cienfuegos

Maximino Huerta-Bravo

Universidad Autónoma Chapingo: Universidad Autonoma Chapingo

Rodolfo Ramírez-Valverde

Universidad Autónoma Chapingo: Universidad Autonoma Chapingo

\section{Glafiro Torres-Hernández}

Colegio de Postgraduados Campus Montecillo: Colegio de Postgraduados

María E. López-Arellano

INIFAP: Instituto Nacional de Investigaciones Forestales Agricolas y Pecuarias

\section{Research Article}

Keywords: nutrition, parasitism, peripartum rise, sheep

Posted Date: February 7th, 2022

DOI: https://doi.org/10.21203/rs.3.rs-1281014/v1

License: (c) (1) This work is licensed under a Creative Commons Attribution 4.0 International License.

Read Full License 


\section{Abstract}

The study was carried out to evaluate the effect of dietary energy and protein levels on the parasitological and hematological response during the peripartum and lactation of grazing Pelibuey ewes. Forty-eight Pelibuey ewes aged 3-5 years and body weight $31 \pm 5 \mathrm{~kg}$ were used. Four groups of 12 ewes, including non-pregnant and productive ewes, were formed. Fecal samples were collected to determine the fecal egg count (FEC) of gastrointestinal nematodes (GINs), and blood samples were also taken to determine the packed cell volume (PCV) and peripheral eosinophil (EOS) count. A factorial treatment design was formulated, where two levels of energy (high, with $2.7 \mathrm{Mcal} / \mathrm{kg}, \mathrm{n}=24$; and low, with $2.3 \mathrm{Mcal} / \mathrm{kg}, \mathrm{n}=24$ ) and two levels of protein (high, with $15.5 \%, n=24$; and low, with $8.7 \%, n=24$ ) were studied. The high dietary protein allowed lower FEC (837 \pm 141 fecal eggs per gram, EPG) and higher PCV (26.5 $\pm 0.5 \%)$ than the low-protein level (1680 \pm 248 EPG and $24.6 \%$, respectively). Higher FEC (1085 \pm 264 EPG and $2709 \pm 359)$ and lower PCV $(26.7 \pm 0.7 \%$ and $21.9 \pm 0.7 \%)$ levels were observed in pregnant and lactating ewes, respectively, compared to non-pregnant ones ( $427 \pm 96$ EPG and $27.7 \pm 0.4 \%$ ). It is concluded that high levels of dietary protein improve the hematological response and reduce the FEC in Pelibuey ewes under grazing conditions. The non-pregnant ewes maintained some resilience and resistance to GIN infection compared to productive ewes.

\section{Introduction}

Gastrointestinal nematodes (GINs) are considered one of the most important diseases in grazing sheep (Torres-Acosta et al., 2019). Of all reported GIN species, Haemonchus contortus is the most prevalent worldwide (Lalramhluna et al., 2020). This is a pathogenic parasite that causes weight loss, severe anemia, ulcerations, congestion of the abomasal mucosa, thickening of the walls, hemorrhagic foci, hyperplasia of the glands with infiltration of lymphocytes and eosinophils, deterioration of the general body condition, and high mortality in susceptible sheep (Mavrot et al., 2015; Notter et al., 2017).

During the productive life of ewes, the peripartum period is very important because they suffer a reduction in immunity associated with the stress of lambing and lactation, which in turn causes favorable conditions for the development of a GIN parasitic phase (David et al., 2020) and, as a consequence, high fecundity of GIN females, which results in high fecal egg count (FEC) and increases the susceptibility to other infections (Hamer et al., 2019). This phenomenon is well known as peripartum rise, spring rise, or lactation rise (González-Garduño et al., 2021) and consists of a transient increase in FEC in ewes (Goldberg et al., 2012). Due to this situation, ewes during peripartum carry the main responsibility for the contamination of pastures with GIN eggs (Hamer et al., 2019).

Also during this period, ewes show physiological and metabolic changes (Kaçar et al., 2021) that increase considerably their nutriment requirements for milk production, and they need satisfy the feeding of one or more lambs (Cabiddu et al., 2020), which also affects their immune response and is reflected in the increased FEC. Nutritional management is vital for ewes to be able to overcome this critical phase and 
ensure defense mechanisms against infectious and parasitic pathogens (Ahmed et al., 2020), in addition to producing strong and healthy lambs.

It is well documented that a balanced diet reduces the magnitude or duration of the peripartum rise by improving the immune response of the ewes. Protein metabolism is that most affected during infection with GINs, due to the loss of blood and the need for the repair of affected tissues (Alam et al., 2020). Therefore, supplementation with protein in the ration can help to improve the resistance and resilience of the host against parasites. Infected animals require more energy to maintain an increase in body weight similar to that of non-infected animals for the development of immunological mechanisms (Méndez-Ortíz et al., 2019). Therefore, the objective of the study was to evaluate the parasitological and hematological response of Pelibuey ewes in grazing during the peripartum supplemented with two levels of dietary energy and protein.

\section{Materials And Methods}

\section{Location}

The study was developed during October to December 2019 at the Experimental Station of Pastures and Forages (EEPF) "Indio Hatuey" of the Matanzas University in the province of Matanzas, Cuba. The climate of the region is Equatorial Savannah with dry summer (Kottek et al., 2006).

\section{Sheep management}

Forty-eight Pelibuey ewes, 3-5 years old of body weight $31 \pm 5 \mathrm{~kg}$ were used. Four groups of 12 ewes were formed randomly (pregnant and non-pregnant), and each group was assigned one diet corresponding to the treatment. The study began at the 13th week of pregnancy with a 15-day period of adaptation to the experimental diets. The ewes were kept in rotational grazing for 6 hours per day. The paddocks were formed with a mixture of Dichantium annulatum and Megathyrsus maximus. After grazing, the animals were distributed into different pens according to the experimental dietary treatment received. The ewes stayed during the afternoon and night in each assigned pen along with their lambs, and they grazed during the day.

\section{Diets and treatments}

The experimental diets had sugar cane as the main ingredient. The combination of two levels of energy (high and low) and two levels of protein (high and low) represented the experimental treatments (Table 1). The sugar cane was processed through solid-state fermentation (Elías et al., 1990). 
Table 1

Ingredients of the diets used in the feeding of the experimental animals.

\begin{tabular}{|lllll|}
\hline \multirow{2}{*}{ Ingredients } & \multicolumn{2}{l}{ Low energy } & \multicolumn{2}{l|}{ High energy } \\
\cline { 2 - 5 } & $\begin{array}{l}\text { Low } \\
\text { protein }\end{array}$ & High & Low & High \\
& protein & Protein & protein \\
& 3 & 3 & 26 & 20.5 \\
\hline Cornmeal (\%) & (LEHP) & (HELP) & (HEHP) \\
\hline Soybean paste flour (\%) & 5 & 20 & 1.0 & 15.0 \\
\hline Sugar cane (\%) & 83 & 65 & 67 & 60.0 \\
\hline Mineral mix (\%) & 0.5 & 0.5 & 0.5 & 0.5 \\
\hline Urea (\%) & 1.5 & 2 & 1.5 & 2.0 \\
\hline Molasses (\%) & 0 & 0 & 4.0 & 2.0 \\
\hline Wheat bran (\%) & 7 & 9.5 & 0 & 0 \\
\hline Dry matter (\%) & 34.9 & 43.3 & 50.1 & 54.5 \\
\hline Energy (Mcal/Kg) & 2.32 & 2.3 & 2.65 & 2.65 \\
\hline Protein (\%) & 8.74 & 16.25 & 8.74 & 15.54 \\
\hline
\end{tabular}


Table 2

Fecal nematode egg count, packed cell volume, and peripheral eosinophil count in Pelibuey ewes infected with gastrointestinal nematodes and fed with two levels of energy and protein.

\begin{tabular}{|c|c|c|c|c|c|c|}
\hline \multirow[t]{2}{*}{ Effect } & \multicolumn{2}{|c|}{ Fecal egg count } & \multicolumn{2}{|c|}{ Packed cell volume (\%) } & \multicolumn{2}{|c|}{$\begin{array}{l}\text { Peripheral } \\
\text { eosinophils } \\
\text { Cells } \times 10^{3} \mu \mathrm{L}\end{array}$} \\
\hline & Mean & SE & Mean & SE & Mean & SE \\
\hline Protein level & * & & * & & ns & \\
\hline High & $837^{a}$ & 141 & $26.5^{\mathrm{a}}$ & 0.46 & $0.73^{a}$ & 59 \\
\hline Low & $1680^{b}$ & 248 & $24.6^{b}$ & 0.59 & $0.77^{a}$ & 74 \\
\hline Energy level & ns & & ns & & ns & \\
\hline High & $1271^{a}$ & 205 & $25.0^{\mathrm{a}}$ & 0.54 & $0.77^{a}$ & 81 \\
\hline Low & $1263^{a}$ & 209 & $25.9^{a}$ & 0.55 & $0.72^{\mathrm{a}}$ & 50 \\
\hline Physiological stage & ** & & ** & & ** & \\
\hline Pregnancy & $1085^{b}$ & 264 & $26.7^{a}$ & 0.73 & $0.71^{\mathrm{ab}}$ & 148 \\
\hline Lactation & $2709^{c}$ & 359 & $21.9^{\mathrm{b}}$ & 0.69 & $0.59^{b}$ & 56 \\
\hline Non-pregnant & $427^{a}$ & 96 & $27.7^{a}$ & 0.4 & $0.90^{a}$ & 79 \\
\hline
\end{tabular}

\section{Samples}

The fecal samples were collected weekly to determine the number of eggs per gram of feces (EPG) by flotation by the McMaster technique (Thienpont et al., 2003) with a minimum sensitivity of 50 EPG.

To obtain the blood samples, vacutainer tubes with ethylenediaminetetraacetate (EDTA) were used, after puncturing the jugular vein. The whole blood was used to determine the packed cell volume (PCV) using the microhematocrit technique, and peripheral eosinophils (EOS) were counted using a Neubauer chamber (Dawkins et al., 1989).

\section{Statistical analysis}

The effect of the physiological stage was analyzed. A factorial treatment design was formulated, where the main effects were energy, at two levels: high energy $(n=24)$ and low energy $(n=24)$. The other main effect was the protein, with high $(n=24)$ and low $(n=24)$ levels. The EPG counts were transformed to 
logarithms $\left(\log _{10} E P G+1\right)$ and the data analyzed using the Mixed procedure of SAS (SAS, 2017), under the following statistical model.

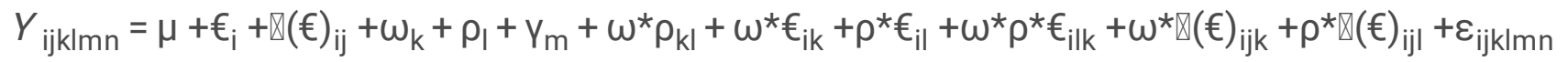

where: $Y_{\mathrm{ijklm}}=$ response variable (EPG, PCV, EOS, etc.); $\mu=$ general mean; $\epsilon_{\mathrm{i}}=$ effect of physiological stage ( $i=$ pregnant, lactation, non-pregnant); $\mathbb{(}(€)_{\mathrm{ij}}=$ fixed effect of nested week on physiological stage $(j=15$, $16,17 \ldots 21$ of pregnancy and $1,2,3 . .7$ of lactation); $\omega_{k}=$ effect of energy level ( $k=$ high and low), $\rho_{l}=$ effect of protein level $\left(\mathrm{I}=\right.$ high and low); $\gamma_{\mathrm{m}}=$ random effect of ewe; $\omega^{\star} \rho_{\mathrm{kl}}=$ interaction between energy and protein; $\omega^{\star} €_{\mathrm{ik}}=$ interaction between energy and physiological stage; $\rho^{\star} €_{\mathrm{il}}=$ interaction between protein and physiological stage; $\omega^{\star} \rho^{\star} \epsilon_{\mathrm{ilk}}=$ interaction between energy, protein and physiological stage; $\omega^{\star} \varangle(€)_{\mathrm{ijk}}=$ interaction of energy nested in the physiological stage; $\rho^{\star} \otimes(€)_{\mathrm{ijl}}=$ interaction between protein and week nested in physiological stage; and $\varepsilon \mathrm{ijk} \mathrm{lm}$ = residual term from repeated measures.

\section{Results}

\section{Effect of energy and protein}

Protein level and physiological stage were the factors that significantly affected FEC and PCV values ( $p \leq$ 0.05). Ewes that received the high protein level, independent of energy level, had lower FEC and higher PCV values. On the other hand, lactating ewes showed the highest values in FEC and PCV while pregnant, and non-pregnant ewes showed no differences between them $(P>0.05)$. The energy level did not affect the values of any of the variables studied (EPG, PCV, or EOS).

\section{Effect of time on physiological stage}

In the peripartum, the FEC increased to values higher than 1800 EPG three weeks before lambing, and a peak was observed at six weeks of lactation. High FECs were maintained during the five weeks of lactation. Throughout peripartum period the FEC was higher in the productive ewes than in the nonpregnant group (Figure 1).

The PCV showed a different response from that of the FEC. The highest PCV was observed in nonpregnant ewes, while in productive ewes the PCV tended to decrease gradually as it approached parturition and during the following weeks of lactation, with a slight tendency to increase from weeks 6 and 7 of lactation (Figure 2).

During gestation, the EOS count was similar to that of non-pregnant ewes (Figure 3); this group of animals showed some resilience and resistance to gastrointestinal parasites compared to the productive ewes.

\section{Effect of protein on physiological stage}


The effect of protein content was evident in FEC and PCV values. Thus, lactating ewes given the high level of dietary protein had lower FEC and higher VCA levels $(P<0.01)$ than the lower-protein-level group, while pregnant and non-pregnant ewes showed no effect of dietary protein (Figure 4).

\section{Interaction between energy and protein with physiological stage}

Lactating ewes fed the high level of protein showed a reduction in FEC. In the case of non-pregnant females, there were no differences attributed to dietary protein and in pregnant ewes the results were not consistent (Figure 5).

\section{Discussion}

Many studies have been carried out to measure the effect of nutritional manipulation in the control of gastrointestinal parasites (Torres-Acosta et al., 2012; Cériac et al., 2017, 2019; Crawford et al., 2020). The FEC observed during the pregnancy and lactation of ewes demonstrated the effect of protein on parasitological response, especially during lactation, although, along with the amount of protein given, some authors suggest that the parasitological response is regulated also by the quality of protein supplemented (Sakkas et al., 2012; Crawford et al., 2020). The effect of dietary protein on the reduction in FEC has been attributed to a replacement of nutrients that are diverted to develop the protective elements of immunity (Hoste et al., 2016). Protein losses due to the effect of GIN infection can be corrected through the intake of dietary protein and, for this reason, protein requirements are higher than currently recommended for non-parasitized animals (Crawford et al., 2020). Méndez-Ortíz et al. (2019) suggest an important relationship between parasitism and dietary energy and protein consumption. An additional supply of energy is required, in addition to protein, for the development of immunological mechanisms (Jones et al., 2011). However, in the present study the energy effect was not observed because the levels provided were sufficient to mount an adequate immune response and therefore the energy level did not show a significant effect on FEC. Apparently energy supplementation is subject to a process of metabolic reprogramming necessary for the development and functioning of the immune system (Kim, 2018). This can generate a diversion of energy to the synthesis of the cellular metabolites necessary for defense processes (Colditz, 2008; Iwasaki et al., 2020).

The increased FEC during the last weeks of pregnancy and the first weeks of lactation is produced by the breakdown of the immunological system (Hernández-Castellano et al., 2019) that provokes an increased FEC. This is associated with several factors that act simultaneously in ewes, such as an energy imbalance and a reduction in the feed intake combined with a low absorption capacity of the intestine that causes poor nutrient use. For the aforementioned, the peripartum rise is linked to increased energy and protein needs for fetal growth, milk production, and tissue repairs (Mahieu and Aumont, 2007; Houdijk, 2008). Other important aspects associated with the high FEC are explained by the massive development of hypobiotic larvae (Falzon et al., 2013) during the immunosuppression that occurs at this stage, which favors parasitic development (Arsenopoulos et al., 2021). 
The PCV is an indicator of an animal's health status because it is closely related to the presence of anemia (Ferreira et al., 2019). This sign is also one of the results of infection with hematophagous nematodes such as H. contortus. The PCV is affected by a high GIN burden (Dos Santos Oliveira 2008) and is considered one of the criteria of resilience and genetic resistance of animals (Cériac et al., 2017) in selection programs for sheep. At the same time that a reduction in PCV occurs during infection, other elements of the immune system are affected, since it has been observed that the number of neutrophils is reduced (Awad et al., 2016). In the present study, a breakdown of immunity during lactation was noted, when eosinophils were drastically reduced after the third week of lactation, coinciding with the reduction in PCV. Protein supplementation helps to reduce FEC, specifically in such critical moments as the last third of pregnancy and lactation, and together with energy supplementation can improve the immune response of ewes in the peripartum (Kyriazakis and Houdijk, 2006). Pathological damage occurs with lower values of PCV of 17-23\% (Arece and López, 2013), although 15\% has been considered as a critical threshold. Values equal or less to critical umbral are dangerous for life (Ferreira et al., 2019). Hematocrit decreases progressively from the beginning of pregnancy, reaching the lowest levels in the second month of lactation (Romero-Escobedo et al., 2018).

Eosinophils are defense cells and act together with immunoglobulins in the control of GINs (Moreau and Chauvin, 2010; Ortolani et al., 2013). Eosinophils, mast cells, and globular leukocytes are effector cells that can selectively secrete cytokines, chemokines, and other mediators in response to helminth infection, contributing to both effector functions and the maintenance of homeostasis (Mitre and Klion, 2021). In the present study, the physiological stage affected the EOS counts. In the peripartum, an increase in the FEC occurred, which triggers the classic signs of eosinophilia together with increases in macrophages and dendritic cells, which contribute to the defense of the host against the challenge (Lechner et al., 2021). But the levels of eosinophils were reduced after the fourth week of lactation, reaching their lowest values at the fifth week, and from the sixth week a recovery in this cell count was noted. Eosinophilia has always been negatively correlated with FEC, which is reflected in a lower parasite burden (Hendawy, 2018), a situation that was observed in non-pregnant ewes with lower EPG and higher EOS counts. In relation to productive ewes, in pregnant and lactating ewes an increased level of eosinophil accumulation in tissues or blood, with marked degranulation, can be seen in parasitic infections (Mitre and Klion, 2021). However, the breakdown of immunity implies a reduction in the EOS count in the middle and at the end of lactation, as observed in the present study.

\section{Conclusions}

It is concluded that feeding with a high level of protein in the diet can improve the GIN resistance of ewes and reduce FEC and increase PCV during lactation under grazing conditions. Physiological stage is the factor that most affects the parasitological and hematological response of Pelibuey ewes. The nonpregnant ewes maintained a certain resilience and resistance to gastrointestinal parasites compared to the ewes in production, and the most critical weeks were those corresponding to the last third of gestation and the first weeks of lactation. 


\section{Declarations}

Funding:The authors declare that no funds, grants, or other support were received during the preparation of this manuscript

Conflicts of interest/Competing interests: The authors declare that they have no conflicts of interest.

Ethics approval: All applicable international, national, and/or institutional guidelines for the care and use of animals were followed.

Consent to participate: Not applicable

Consent for publication: Not applicable

Availability of data and material: The datasets generated are available from the corresponding author on reasonable request

Code availability: Not applicable

Authors' contributions: All authors contributed to the study conception and design. Material preparation, data collection and analysis were performed by Yoel López Leyva, Javier Arece García. The first draft of the manuscript was written by Roberto González Garduño, Glafiro Torres Hernández, Maximino Huerta Bravo, Rodolfo Ramírez Valverde, Ma. Eugenia López Arellano and all authors commented on previous versions of the manuscript. All authors read and approved the final manuscript.

\section{References}

1. Ahmed, M.H., Wilkens, M.R., Möller, B., Ganter, M. and Breves, G., 2020. Blood leukocyte composition and function in periparturient ewes kept on different dietary magnesium supply BMC veterinary research, 16, 1-14 (BMC Veterinary Research)

2. Alam, R.T.M., Hassanen, E.A.A. and El-Mandrawy, S.M.A., 2020. Heamonchus Contortus infection in Sheep and Goats: alterations in haematological, biochemical, immunological, trace element and oxidative stress markers Journal of Applied Animal Research, 48, 357-364

3. Arece, J. and López, Y., 2013. Validation of the FAMACHA @ method for detecting anemia in Cuban Pelibuey sheep Pastos y Forrajes, 36, 479-484

4. Arsenopoulos, K. V., Fthenakis, G.C., Katsarou, E.I. and Papadopoulos, E., 2021. Haemonchosis: A challenging parasitic infection of sheep and goats Animals, 11, 1-29

5. Awad, A.H., Ali, A.M. and Hadree, D.H., 2016. Some haematological and biochemical parameters assessments in sheep infection by Haemonchus contortus Tikrit Journal of Pure Science, 21, 11-15

6. Cabiddu, A., Dattena, M., Decandia, M., Molle, G., Lopreiato, V., Minuti, A. and Trevisi, E., 2020. The effect of parity number on the metabolism, inflammation, and oxidative status of dairy sheep during 
the transition period Journal of Dairy Science, 103, 8564-8575 (American Dairy Science Association)

7. Cériac, S., Archimède, H., Feuillet, D., Félicité, Y., Giorgi, M. and Bambou, J.C., 2019. Supplementation with rumen-protected proteins induces resistance to Haemonchus contortus in goats Scientific Reports, 9, 1-10

8. Cériac, S., Jayles, C., Arquet, R., Feuillet, D., Félicité, Y., Archimède, H. and Bambou, J.C., 2017. The nutritional status affects the complete blood count of goats experimentally infected with Haemonchus contortus BMC Veterinary Research, 13, 1-10 (BMC Veterinary Research)

9. Colditz, I.G., 2008. Six costs of immunity to gastrointestinal nematode infections Parasite Immunology, 30, 63-70

10. Crawford, C.D., Mata-Padrino, D.J., Belesky, D.P. and Bowdridge, S.A., 2020. Effects of supplementation containing rumen by-pass protein on parasitism in grazing lambs Small Ruminant Research, 190, 106161 (Elsevier)

11. David, C.M.G., Costa, R.L.D., Parren, G.A.E., Rua, M.A.S., Nordi, E.C.P., Paz, C.C.P., Quirino, C.R., Figueiredo, R.S. and Bohland, E., 2020. Hematological, parasitological and biochemical parameters in sheep during the peripartum period Revista Colombiana de Ciencias Pecuarias, 33, 81-95

12. Dawkins, H., Windon, R. and Eagleson, G., 1989. Eosinophil responses in sheep selected for high and low responsiveness to Trichostrongylus colubriformis International Journal for Parasitology, 19, 199-205

13. Elías, A., Lezcano, O., Lezcano, P., Cordero, J. and Quintana, L., 1990. Reseña descriptiva sobre el desarrollo de una tecnología de enriquecimiento proteico de la caña de azúcar mediante fermentación en estado sólido (saccharina). Revista Cubana de Ciencias Agrícolas, 24, 1-12

14. Falzon, L.C., Menzies, P.I., Shakya, K.P., Jones-Bitton, A., Vanleeuwen, J., Avula, J., Jansen, J.T. and Peregrine, A.S., 2013. A longitudinal study on the effect of lambing season on the periparturient egg rise in Ontario sheep flocks Preventive Veterinary Medicine, 110, 467-480 (Elsevier B.V.)

15. Ferreira, J., Sotomaior, C.S., Bezerra, A.C.D., da Silva, W.E., Leite, J.H.G.M., de Sousa, J.E.R., Viz, de F.F.B.J. and Façanha, D.A.E., 2019. Sensitivity and specificity of the FAMACHAC system in tropical hair sheep Tropical Animal Health and Production, 51, 1767-1771

16. Goldberg, V., Ciappesoni, G. and Aguilar, I., 2012. Genetic parameters for nematode resistance in periparturient ewes and post-weaning lambs in Uruguayan Merino sheep Livestock Science, 147, 181-187

17. González-Garduño, R., Arece-García, J. and Torres-Hernández, G., 2021. Physiological, immunological and genetic factors in the resistance and susceptibility to gastrointestinal nematodes of sheep in the peripartum period: A review Helminthologia (Poland), 58, 134-151

18. Hamer, K., Mclntyre, J., Morrison, A.A., Jennings, A., Kelly, R.F., Leeson, S., Bartley, D.J., Chaudhry, U., Busin, V. and Sargison, N., 2019. The dynamics of ovine gastrointestinal nematode infections within ewe and lamb cohorts on three Scottish sheep farms Preventive Veterinary Medicine, 171, 104752 (Elsevier) 
19. Hendawy, S.H.M., 2018. Immunity to gastrointestinal nematodes in ruminants: effector cell mechanisms and cytokines Journal of Parasitic Diseases, 42, 471-482 (Springer India)

20. Hernández-Castellano, L.E., Moreno-Indias, I., Sánchez-Macías, D., Morales-delaNuez, A., Torres, A., Argüello, A. and Castro, N., 2019. Sheep and goats raised in mixed flocks have diverse immune status around parturition Journal of Dairy Science, 102, 8478-8485 (American Dairy Science Association)

21. Hoste, H., Torres-Acosta, J.F.J., Quijada, J., Chan-Perez, I., Dakheel, M.M., Kommuru, D.S., MuellerHarvey, I. and Terrill, T.H., 2016. Interactions Between Nutrition and Infections With Haemonchus contortus and Related Gastrointestinal Nematodes in Small Ruminants, (Elsevier Ltd)

22. Houdijk, J.G.M., 2008. Influence of periparturient nutritional demand on resistance to parasites in livestock Parasite Immunology, 30, 113-121

23. Iwasaki, Y., Takeshima, Y. and Fujio, K., 2020. Basic mechanism of immune system activation by mitochondria Immunological Medicine, 43, 142-147 (Taylor \& Francis)

24. Jones, L.A., Houdijk, J.G.M., Sakkas, P., Bruce, A.D., Mitchell, M., Knox, D.P. and Kyriazakis, I., 2011. Dissecting the impact of protein versus energy host nutrition on the expression of immunity to gastrointestinal parasites during lactation International Journal for Parasitology, 41, 711-719 (Australian Society for Parasitology Inc.)

25. Kaçar, C., Kaya, S., Kuru, M., Erkiliç, E.E., Öğün, M., Oral, H. and Demir, M.C., 2021. Determination of natural antibodies, beta-hydroxybutyric acid, and non-esterified fatty acid levels in the serum of peripartum Tuj and Hemsin sheep Veterinary World, 14, 1002-1006

26. Kim, J., 2018. Regulation of Immune Cell Functions by Metabolic Reprogramming Journal of Immunology Research, 2018, 1-12

27. Kottek, M., Grieser, J., Beck, C., Rudolf, B. and Rubel, F., 2006. World map of the Köppen-Geiger climate classification updated Meteorologische Zeitschrift, 15, 259-263

28. Kyriazakis, I. and Houdijk, J., 2006. Immunonutrition: nutritional control of parasites Small Ruminant Research, 62, 79-82

29. Lalramhluna, M., Bordoloi, G., Pandit, S., Baidya, S., Joardar, S.N., Patra, A.K. and Jas, R., 2020. Parasitological and immunological response to Haemonchus contortus infection: Comparison between resistant Garole and susceptible Sahabadi sheep Veterinary Parasitology: Regional Studies and Reports, 22, 100477 (Elsevier)

30. Lechner, A., Bohnacker, S. and Esser-von Bieren, J., 2021. Macrophage regulation \& function in helminth infection Seminars in Immunology, 53, 101526 (Elsevier Ltd)

31. Mahieu, M. and Aumont, G., 2007. Periparturient rise in Martinik Hair Sheep and perspectives for gastrointestinal nematode control Tropical Animal Health and Production, 39, 387-390

32. Mavrot, F., Hertzberg, H. and Torgerson, P., 2015. Effect of gastro-intestinal nematode infection on sheep performance: A systematic review and meta-analysis Parasites and Vectors, 8, 1-11 (Parasites \& Vectors) 
33. Méndez-Ortíz, F.A., Sandoval-Castro, C.A., Vargas-Magaña, J.J., Sarmiento-Franco, L., Torres-Acosta, J.F.J. and Ventura-Cordero, J., 2019. Impact of gastrointestinal parasitism on dry matter intake and live weight gain of lambs: A meta-analysis to estimate the metabolic cost of gastrointestinal nematodes Veterinary Parasitology, 265, 1-6 (Elsevier)

34. Mitre, E. and Klion, A.D., 2021. Eosinophils and helminth infection: protective or pathogenic? Seminars in Immunopathology, 43, 363-381 (Seminars in Immunopathology)

35. Moreau, E. and Chauvin, A., 2010. Immunity against Helminths: Interactions with the Host and the Intercurrent Infections Journal of Biomedicine and Biotchnology, 2010, 1-9

36. Notter, D.R., Burke, J.M., Miller, J.E. and Morgan, J.L.M., 2017. Factors affecting fecal egg counts in periparturient Katahdin ewes and their lambs Journal of Animal Science, 95, 103-112

37. Ortolani, E.L., Leal, M.L. do R., Minervino, A.H.H., Aires, A.R., Coop, R.L., Jackson, F. and Suttle, N.F., 2013. Effects of parasitism on cellular immune response in sheep experimentally infected with Haemonchus contortus Veterinary Parasitology, 196, 230-234 (Elsevier B.V.)

38. Romero-Escobedo, E., Torres-Hernández, G., Becerril-Pérez, C.M., Alarcón-Zúñiga, B., Apodaca-Sarabia, C.A. and Díaz-Rivera, P., 2018. A comparison of criollo and suffolk ewes for resistance to haemonchus contortus during the periparturient period Journal of Applied Animal Research, 46, 1723

39. Sakkas, P., Houdijk, J.G.M., Athanasiadou, S. and Kyriazakis, I., 2012. Sensitivity of periparturient breakdown of immunity to parasites to dietary protein source Journal of Animal Science, 90, 39543962

40. SAS, 2017. SAS/STAT User's Guide, Release 6. S. Inst. (ed), (Cary, NC, USA)

41. Thienpont, D., Rochette, F. and Vanparijs, O.F.J., 2003. Diagnosing helminthiasis by coprological examination, Third (Janssen Research Foundation: Beerse, Belgium)

42. Torres-Acosta, J.F., Hoste, H., Sandoval-Castro, C.A., Torres-Fajardo, R.A., Ventura-, J., González-pech, P.G., Mancilla-montelongo, M.G. and Ojeda-Robertos, N.F., 2019. The " Art of War" against gastrointestinal nematodes in sheep and goat herds of the tropics Revista Académica Ciéncia Animal, 17, 39-46

43. Torres-Acosta, J.F.J., Sandoval-Castro, C.A., Hoste, H., Aguilar-Caballero, A.J., Cámara-Sarmiento, R. and Alonso-Díaz, M.A., 2012. Nutritional manipulation of sheep and goats for the control of gastrointestinal nematodes under hot humid and subhumid tropical conditions Small Ruminant Research, 103, 28-40 (Elsevier B.V.)

\section{Figures}




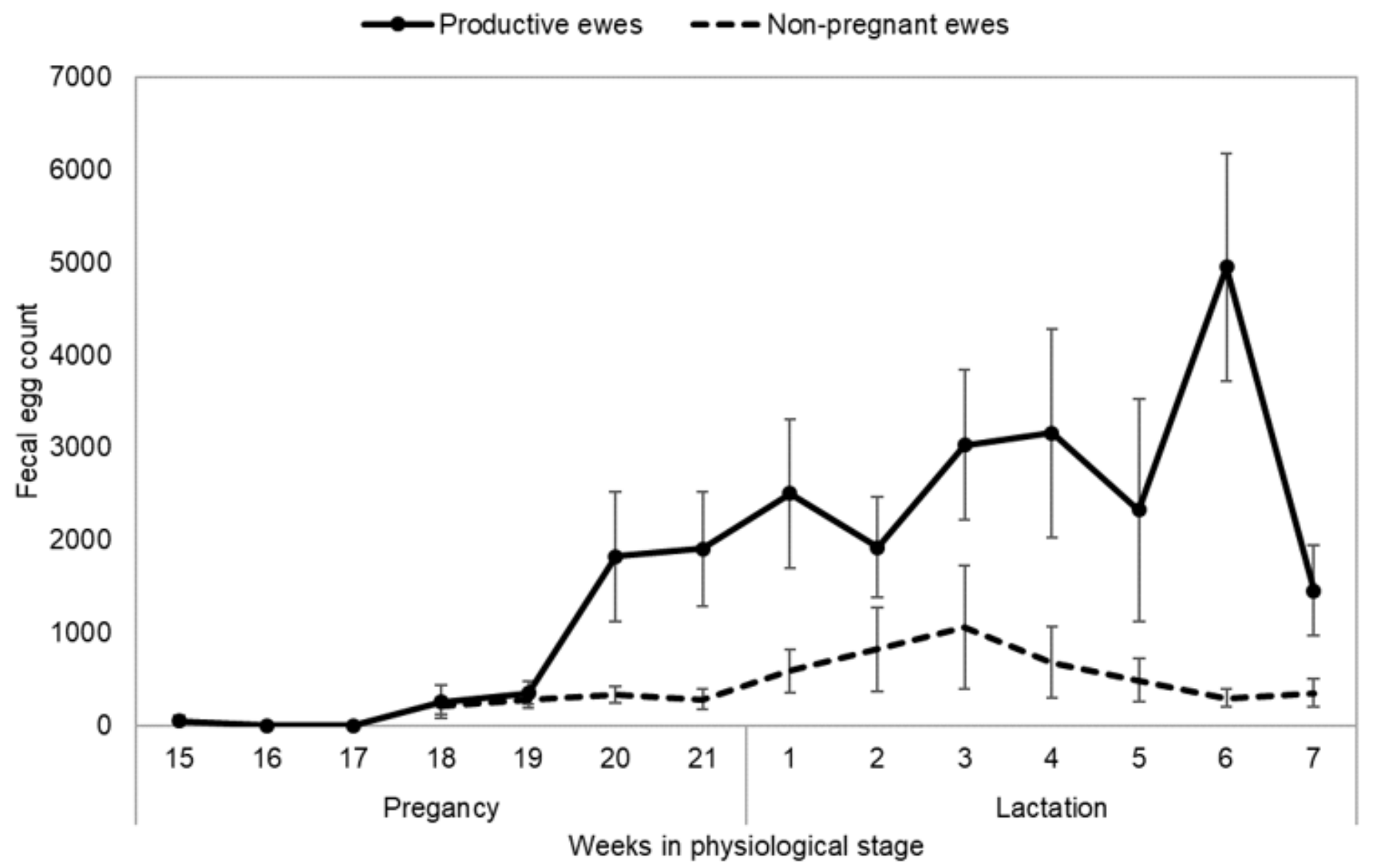

Figure 1

Dynamic of fecal egg count in productive and non-pregnant Pelibuey ewes infected with gastrointestinal nematodes at grazing. 
-Productive ewes $\quad . . .$. Non-pregnant ewes

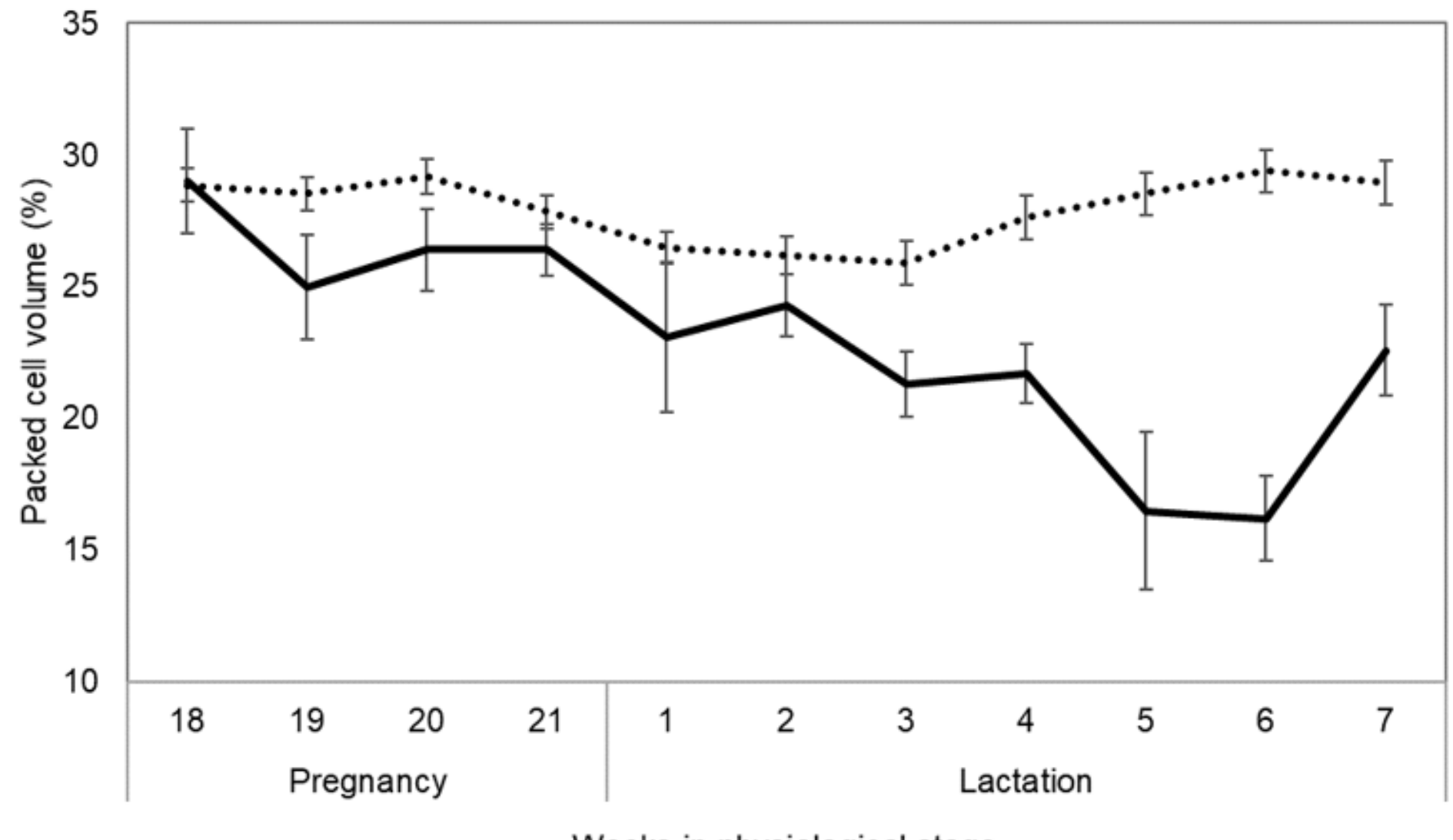

Weeks in physiological stage

Figure 2

Evaluation of packed cell volume in productive and non-pregnant Pelibuey ewes infected in grazing with gastrointestinal nematodes. 


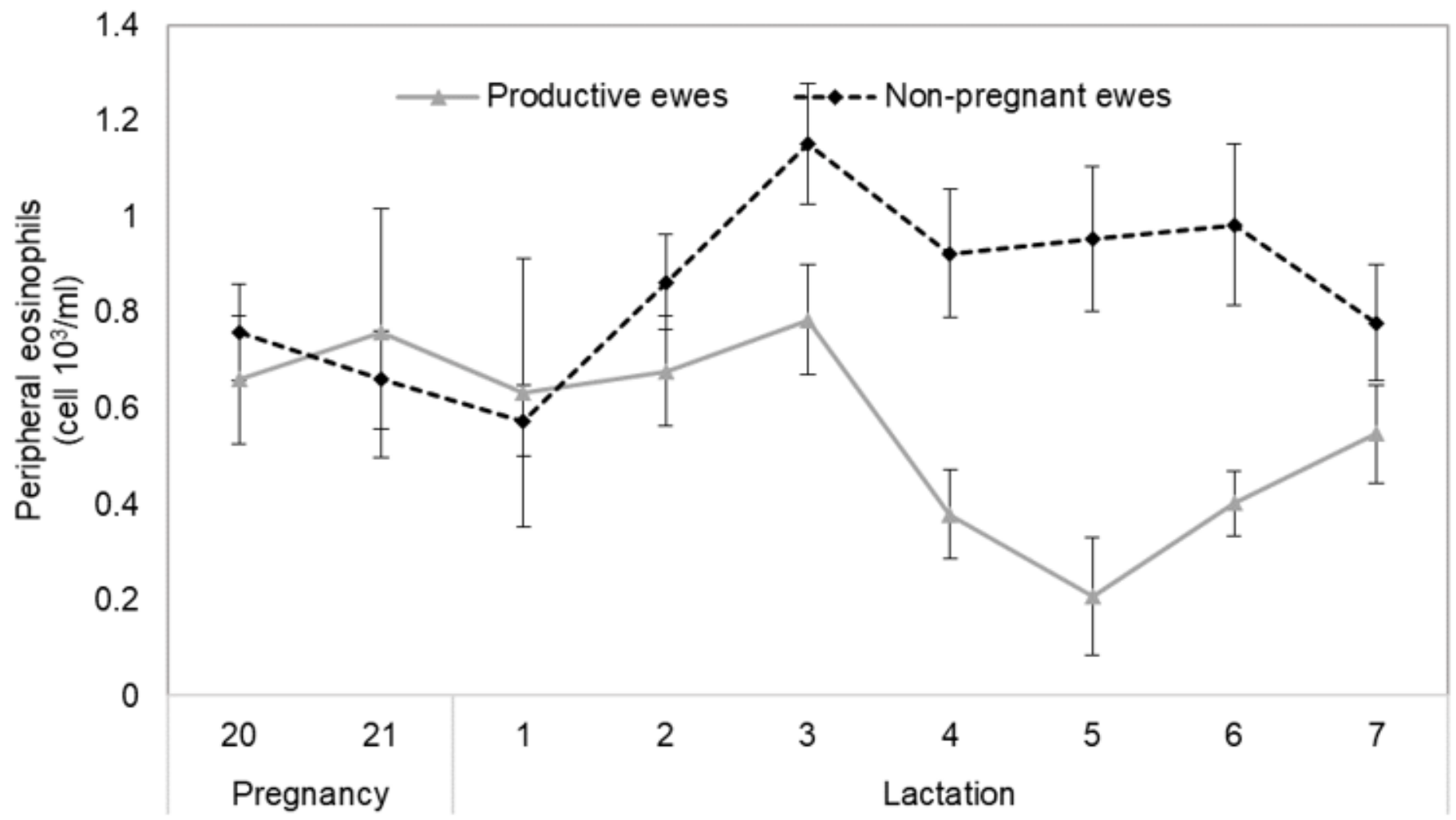

Weeks in physiological stage

Figure 3

Dynamics of peripheral eosinophils count in productive and non-pregnant Pelibuey ewes infected in grazing with gastrointestinal nematodes.

a) Fecal egg count

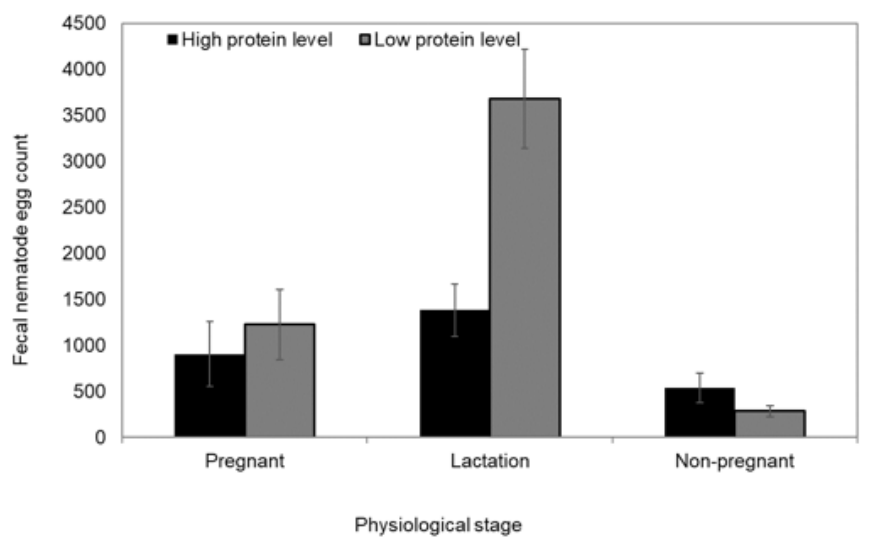

b)Packed cell volume

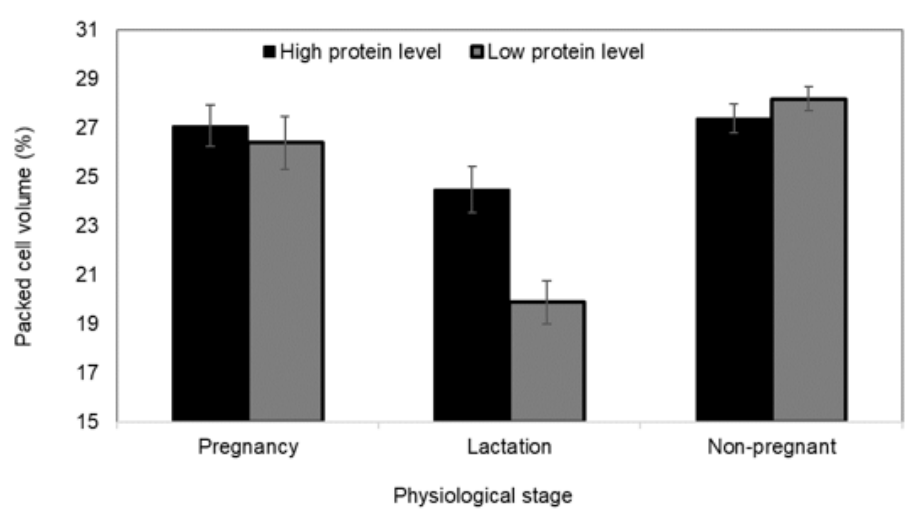

Figure 4 
Interaction of dietary protein level and physiological stage on fecal egg count (a), packed cell volume (b) in pelibuey ewes under grazing conditions.

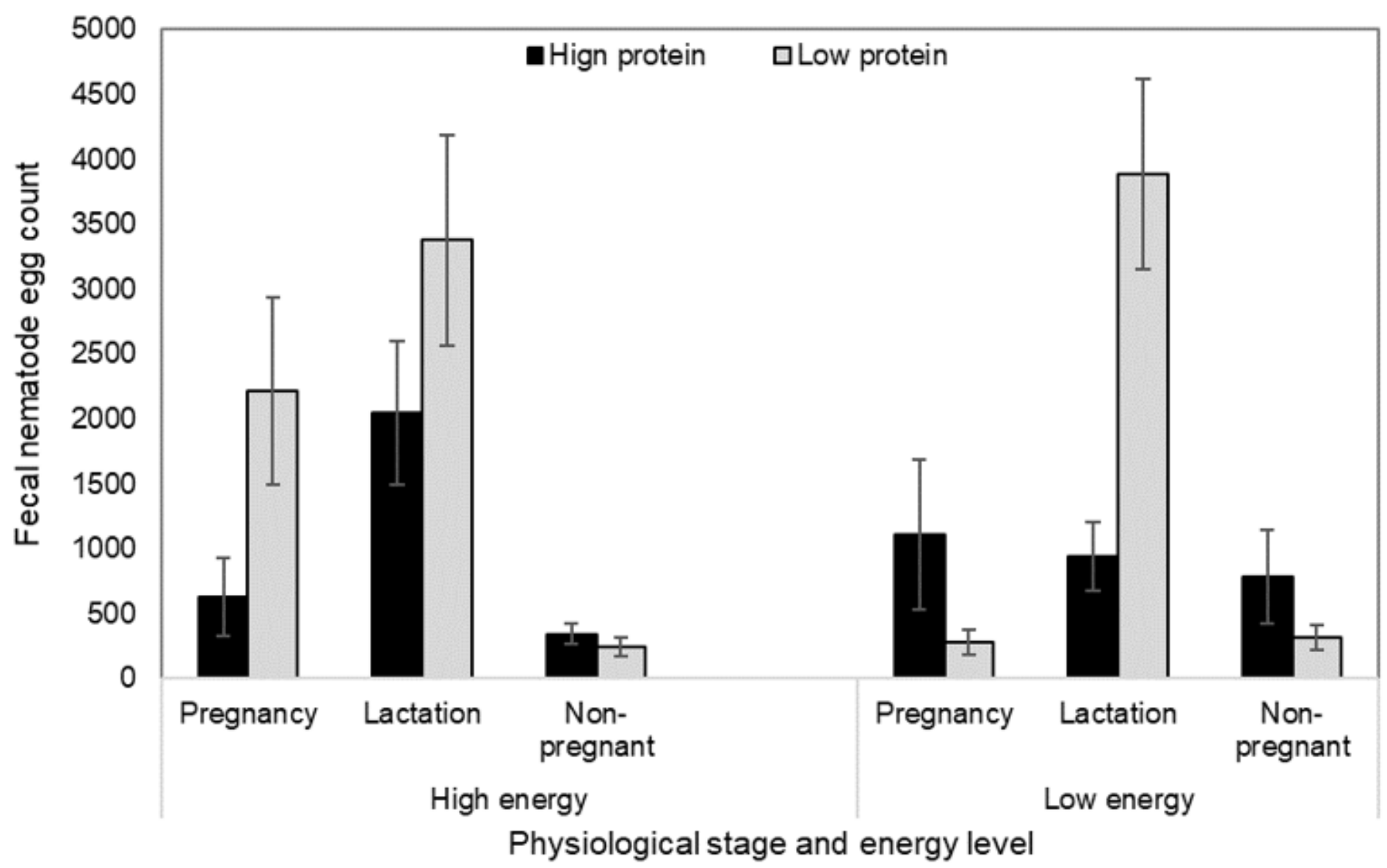

Figure 5

Interaction of dietary protein and energy with physiological stage on fecal egg counts in pelibuey ewes infected in grazing with gastrointestinal nematodes. 